\title{
The House that Engst Built
}

Alison Dangerfield, Heritage Advisor Architect, New Zealand Historic Places Trust, Wellington

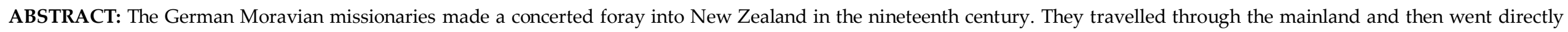

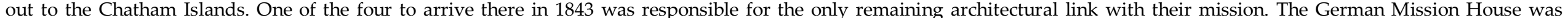

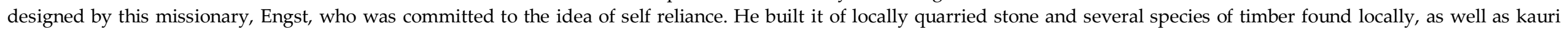
brought from the mainland. It was constructed in the 1860s - a functional, straightforward building, fit for its purpose.

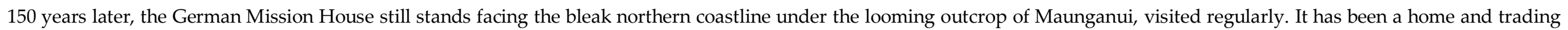
post, and until a few years ago was inhabited. However, in recent years it has been in danger of collapse.

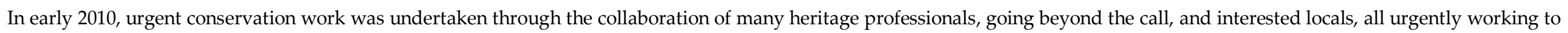
prevent its deterioration and collapse. The story of its conservation is one of efforts against the rugged climate.

The Chatham Islands hold a mystical quality for many New Zealanders. They seem far away and are thought to be a place of rugged landscape, bad weather, tribal ructions and generous sea life. The history of human habitation is as rich here as anywhere in New Zealand however it has limited resources for its people to care for its evidence. Places of known archaeology cover the islands. A clutch of 12 historic buildings were registered in the early 1990s, however three no longer exist. It was with this vulnerability in mind that the New Zealand Historic Places Trust (NZHPT) helped to organise work on a conservation project for the German Mission House when its owners let us know that the walls were moving.
Waitangi West is on the northern coast of Chatham Island in an area that is farmed by a few families. It is around 90 minutes drive on metal road from the main town Waitangi, passing the Te Whanga Lagoon and going beyond the long stretch of Petre Bay to the northwest. The Tuanui family has held a sizeable holding here for many years.

A small scaled cottage sits at the foot of the Maunganui Bluff. The cottage has a spectacular setting. It sits on a slight rise above surrounding flat farm land near the coast. Behind it rises the vast basalt outcrop of Maunganui, a volcanic outcrop dated to five million years, and is perhaps the best known landscape feature of Chatham Island. The cottage provides the only architectural evidence of the presence of New Zealand's sole Moravian German mission.

In 1842, the Gossner Mission in Germany sent five mission brothers to New Zealand: Schirmeister, Müller, Beyer, Bauke and Engst. Missionaries had been coming to New Zealand in numbers, and the brothers sailed in and out, up the South Island looking for a place to proffer their missions and live within their unsponsored means. Every spot on the mainland they tried seemed to be taken already and their means did not allow them the ability to explore. A suggestion to try the Chatham Islands, where it was assumed that the inhabitants were completely without spiritual guidance (there not being any mission to date), set their direction promptly. 
In February 1843 they arrived at Wakaroa or Port Hutt. Here the brothers were immediately taken into the Māori communities; this was at the time when Mōriori were still enslaved. To learn the language and to begin their relationship, which they saw in terms of spiritual salvation and earnest hard work, the five moved apart. Schirmeister and Müller first settled at Nga Tikitiki, Bayer and Baucke several miles further and Engst at Taoroa before moving along the coast to the northeast part of the island.

And so began Engst's 50 years on the island a period of time marked by hardship, self reliance and frugal living. The Māori were not in need of the ministrations of the five but received them in return for labour or other reluctant payment by the missionaries. Diaries and letters provide information of the struggle to live, the lack of success of their Christian mission and a mental picture of each of the missioners. Engst kept his diary for over 50 years, Mehr als FünfzigJahre [More than Fifty Years], in which he wrote of his trials. Diaries relate daily life, Christian zeal and dealings with local Māori. They also relate cruelty by some of the missionaries towards their own family group. There are stories of violence against men, women and children, coercion into marriage, elopement, and food and accommodation deprivation. Engst, in his punishing behaviour, is described by Sheila Natusch as the "classical repressed psychopath ... a tormented destructive volcano of a man."1

However, the missionaries made a significant contribution to the economy and lifestyle of the inhabitants. While they made no converts, they did have a significant place in introducing large-scale horticulture, sheep farming, ship building and literacy. They were committed to the idea of self reliance.

The German Mission House was designed and built between 1866-68 by Johannes Engst with Johann Baucke and Baucke's son William. ${ }^{2}$ Engst and Baucke had been on the island for 20 years by this stage. It was one of several buildings at the Maunganui location and one of many that the missioners built. It is

${ }^{1}$ Natusch Hell and High Water $\mathrm{p} 87$.

2 In Natusch's Hell and High Water records that William Baucke was born on the Chathams and spent much of his early life with the Mōriori people. In later life wrote about his experiences and the Mōriori life and language. Although his attitudes were questioned, he has been a valuable and unique source of information on aspects of Mōriori life. their only surviving building.

Its site on the far northwestern coastline feels remote. There are a few houses in the vicinity. Jo Tuanui worked the farm with her husband Pat until he died a couple of years ago. Their son returned to the island to join the fishing fleet out of Waitangi. Jo operates the farm mostly alone these days and retains concern for the German Mission House and hope for its future.

The German Mission House has a simple rectangular form, with a gabled roof. The ground floor is built from tuff or basalt blocks. These were hewn from the spot where the house was built, forming a cellar beneath the west end. The main north elevation has three paned casement windows and a door, and reflects the internal arrangement with three rooms, the middle being the largest. There are timber floors, internal walls of timber-frame with ponga log infill and plaster lining and a corrugated iron roof. The three spaces in the roof were used as bedrooms, the two end rooms lit with windows in the gable ends, with the east window now missing. Access to the upper storey is by a staircase near the western end of the building. At some stage the exterior stonework has been lime-plastered 
and the original thatched roof replaced with corrugated iron. In early times the building had a verandah and its foundation line is still visible. A lean-to has been added on the south side and stone foundations remain of what possibly was an earlier lean-to. There are two original chimneys, one on the west elevation and one on the south.

This building represents the pioneering period of New Zealand architecture and is a "second generation" building, being built of permanent materials rather than providing temporary shelter. The cottage is built largely of local stone and wood, and reflects the missionaries' attitudes. Such buildings in stone are rare in New Zealand, and this is the only example on the Chatham Islands.

One hundred and fifty years after its construction, the German Mission House still stands facing the bleak northern coastline under the looming outcrop of Maunganui. It has been a home and trading post, and was lived in until a few years ago. Despite its remote location, it is a much visited site on the island, and regularly, groups drive a $1 / 2$ day round trip out to see it. In recent years deterioration has worried the owner. In 2009, urgent conservation work was planned through the collaboration of NZHPT, architects, an engineer, a stonemason and an enthusiastic group of local people.

This was not the first time that conservation work had been undertaken. In 1997 Chris Cochran visited the German Mission House and determined essential repairs. A specification of repairs was prepared and, in 1998, Peter Reed Conservation Architect with Salmon Reed and Campbell Ewing stonemason and stone sculptor spent two weeks at the site repairing the stonework. In 2000 a new steel roof and steel cladding over the west wall were added. In 2005 a conservation plan was written by Chris Cochran following a further visit to the island and building measurements were taken for drawings.

In 2009 following Jo Tuanui's communications, I visited the house and took measurements to gauge the levels of alignment of the block walls. It was clear that movement had occurred. The exterior walls were at a lean and the upper level joists and lintels indicated that a separation was occurring. It was with continuing and accelerating deterioration in mind that the NZHPT and the owners joined forces to stabilize the building.

An application for funding was made to the National Heritage Preservation Incentive Fund administered by the NZHPT for the Crown. The Board of the NZHPT considers requests for funding conservation projects aimed at helping private owners of Category I buildings who have no opportunity to apply to other funding sources. Nationwide a pool of $\$ 500,000$ was allocated in 2009 to worthy projects. The German Mission House was considered a good contender. However the Chatham Islands presented some very specific issues.

Historic places on the Chatham Islands are evidently at the extreme end of vulnerability. There is a high level of loss and potential for loss. The causes of deterioration are demolition, removal of materials for other purposes, weathering, the effects of long term deferred maintenance, and lack of appropriate materials and labour when maintenance does take place. The three lost historic places have met different ends - Tommy Solomon's House at an exposed site at Owenga is now a ruin with its foundations only in place. Materials have been progressively taken from the site. Hunts Forge on Pitt Island is understood to 
have burnt down and a new lodge is presently being planned for its site. The Zimmerman House (on the northwest coast) has been confirmed demolished with little known about the state of the house at the time.

Generally, there is an extremely high level of local understanding of the importance of the German Mission House by the islanders and an intention to use all their skills and available materials to manage the maintenance of the house in the same way as they have managed most things - on their own. They see it as an important opportunity for increased tourism.

Skilled construction labour is scarce on the islands. There are no stonemasons, builders or painters on the island. Chatham Islanders generally cope with the lack of labour by not doing repairs - resulting in deteriorating buildings and ultimately loss. They may undertake the work themselves using any labour available - usually semi-skilled. In rare circumstances, skilled labour from the mainland is engaged.

The owners of the German Mission House are not skilled builders or tradespeople. They are farmers and fishers - with some building skills and much determination. With their friends and family they intended to be fully involved in the house. The contributions the NZHPT could make would promote appropriate choices and methods of conservation.

The provision of labour from the mainland needed to be sensitively handled to avoid the loss of goodwill generally. Goodwill had been built up remarkably since the incentive fund programme was implemented in the conservation of Nairn House at Waitangi on the island. NZHPT was now seen as an organisation that returned and could help. The work that Chris, Peter and Campbell carried out in 1998 set a good example and a precedent. They were knowledgeable about the cottage and their assistance then, and since, produced successful outcomes. Repeating that experience and building on the relationship with the owners was likely to lead to a successful outcome.

Peter Reed expressed interest in assisting a second time and his knowledge of the German Mission House in particular would be helpful. I put together a project team of: Chris Cochran of Wellington, conservation architect and advisor; Peter Reed of Auckland, conservation architect, builder and stonemason; Graham Ball of Auckland, stonemason and builder; and Wynn Clark consulting structural engineer. The project would rely on locally sourced materials as much as possible and further shipped materials. Stocks of timber on the island would be used and stone would be cut locally. Jo Tuanui offered to mill a stand of macrocarpa for the project.

Timing of the project was crucial. From the point when funds were approved in October 2009 to the end of congenial weather in April 2010, a window of six months allowed for final planning, site testing, final design, shipping, construction and Christmas (when islanders leave the island to join family on the mainland). To complete the final design work, the site testing was piggy-backed to another repairs project in the area at the Ponga Whare at Wharekauri.

The project team planned a method to stabilize the movement which was both affordable and achievable. The remote location made the project twice as expensive as it would have been on the mainland and added many constraints. Consideration needed to be given to the aesthetic appearance of any new materials given the heritage significance of the building. 
It was proposed to install tie-rods at ceiling level through the building at strategic locations which were to pass through a ribbon board on the exterior of the walls. The ribbon board was to distribute the point load from the tie-rods. This would require drilling through the $500 \mathrm{~mm}$ thick masonry walls with a diamond tipped water lubricated core drill. A stainless steel tension strap could extend around the building attached to the ribbon board to provide some continuity in tension to the ribbon board during a seismic event. Peter Reed and Graham Ball would need to bring specialized equipment over from the mainland with pre-fabricated stainless steel components, timber for the ribbon board and the tie-rods.

A ship departs from Napier around once a month in summer. Graham Ball arranged a covered trailer full of equipment and material to be sourced in Auckland and driven to meet the ship. Equipment extended to a special core-drilling drill and bit, petrol powered diamond tipped blade saw for cutting stone, drills, grinders, drop saw, demountable work benches, masonry hand tools, pulley apparatus, tarpaulins, ladders, a complete array of carpentry hand tools and laser levelling device, router, and drill press. Light- weight scaffolding and planks were sourced locally and electric power was provided by Jo's portable diesel generator. A rainwater catchment tank of 1,000 litres was already on site.

Graham and Peter left Napier on the ship Baldur on 31 March 2010 for the around 40 hour sailing venture. The Baldur is a 35 year old Norwegian-built fishing vessel converted to carry freight and, on a return trip, livestock from the island to markets on the mainland. Peter and Graham were to be met by Jo Tuanui and taken out to the site for three weeks of intensive work before doing the return trip on the Baldur. The work needed to be closed off and finished within that timeframe. This was expected to be the last sailing for some weeks.

The work was carried out in the first three weeks of April 2010. Graham Ball and Peter Reed had willing assistance from local people organised by Jo Tuanui.

The ribbon board was temporarily attached to the wall and the core drilling commenced. Water for the drilling process was pumped from a back-pack sprayer direct to the drill in place of mains pressure which would usually be used. The specialised drill has a built-in levelling system and a set square screwed to the ribbon board enabled the drill to be guided square to the wall surface. Following the drilling process the tie-rods were installed but only tightened up after mortar packing had been placed between the ribbon board and the wall to take up any gaps. The torque required to pull the tie-rod up was compared for each location. At one point, a portion of the wall was actually drawn in which indicated that the wall was free to move but in most locations no movement was detected.

On the west wall, at some time in the past, the stone chimney had collapsed and had damaged the flanking walls which formed the gable end. The work now involved dismantling and rebuilding a portion of wall between the chimney and the window, the replacement of a rusted steel lintel over the fireplace, replacement of the timber lintel over the window and reconstruction of the section of wall above the window up to the height of the ceiling.

Stone for the wall rebuilding was cut from large portions adjacent to the site. Most rocks then required splitting since the cut could not be completed right through. The rough cut 
stone was then carried to the work site and trimmed as necessary to fit the wall. A bedding mortar comprised of hydrated lime, Portland cement and sand was used to secure each block in place. The sand was sourced from the adjacent sand dunes.

This project has been more than time and materials paid. Peter and Graham carried out the work in fairly rough conditions with long days and a robust climate. It was vital to get the work done and leave the cottage safe for winter.

During the visit, an assessment of other repair work needed for the cottage was carried out, and a refreshing sideline visit to give advice on the conservation of some caves of importance to Mōriori was made. Peter and Graham talk of the generous meals of beef, the hard beds, the remote location and the willingness of up to 30 locals to help. The New Zealand Historic Places Trust is very pleased to have been instrumental in getting this work done. 


\section{REFERENCES}

Natusch, Sheila Hell and High Water-A German Occupation of the Chatham Islands 1843-1910 [Christchurch]: The Caxton Press, 1992

Richards, Rhys and Bill Carter A Decade of Disasters: the Chatham Islands from 1866-1875 Porirua: Paremata Press, 2009.

Reed, Peter Report on Structural Upgrade-Wall Tie-rod Installation, Auckland: April 2010.

NZHPT Registration Report for the German Mission House, registered 21 November 1991. 